\title{
Electrochemistry of $\left[\operatorname{Ru}(b p y)_{3}\right]^{2+}$ and $\left[\operatorname{Ru}(\text { phen })_{3}\right]^{2+}$ inserted in Nafion membranes studied in the ionic liquid $\mathrm{HMImPF}_{6}$
}

\author{
M. J. Gálvez-Vázquez ${ }^{1,2}$, J.L. Gárate-Morales ${ }^{1}$, J. R. Cerna-Cortez ${ }^{1}$ and R. Aguilar-Sánchez ${ }^{1, *}$ \\ ${ }^{1}$ Facultad de Ciencias Químicas, Benemérita Universidad Autónoma de Puebla, 72570, Puebla, \\ México. \\ ${ }^{2}$ University of Bern, Department of Chemistry and Biochemistry, Freiestrasse 3, CH-3012 Bern, \\ Switzerland. \\ *E-mail: rocio.aguilar@ correo.buap.mx, ras747698@ gmail.com
}

doi: $10.20964 / 2020.12 .78$

Received: 25 July 2020 / Accepted: 23 October 2020 / Published: 31 October 2020

The electrochemical properties of tris(2,2'-bipyridine)ruthenium (II) dichloride $\left(\left[\mathrm{Ru}(\mathrm{bpy})_{3}\right]^{2+}\right)$, and tris(1,10-phenantroline)ruthenium (II) dichloride $\left(\left[\mathrm{Ru}(\mathrm{phen})_{3}\right]^{2+}\right)$ complexes inserted in Nafion membranes were studied in the ionic liquid (IL) 1-hexyl-3-methylimidazolium hexafluorophosphate $\left(\mathrm{HMImPF}_{6}\right)$. The wide potential window provided by the IL, allows for the study of the redox properties without using organic solvents. The voltammetric patterns revealed reversible reduction waves for bpy and phen ligands and for the oxidation signal of $\mathrm{Ru}(\mathrm{II}) / \mathrm{Ru}(\mathrm{III})$ similar to those observed in aqueous and organic solvents.

Keywords: Nafion, $\left[\mathrm{Ru}(\mathrm{bpy})_{3}\right]^{2+},\left[\mathrm{Ru}(\mathrm{phen})_{3}\right]^{2+}$, ionic liquid, voltammetry.

\section{FULL TEXT}

(C) 2020 The Authors. Published by ESG (www.electrochemsci.org). This article is an open access article distributed under the terms and conditions of the Creative Commons Attribution license (http://creativecommons.org/licenses/by/4.0/). 